\title{
INTRASPECIFIC VARIATIONS OF 16S MITOCHONDRIAL GENE SEQUENCES OF YELLOW RICE STEM BORER, Scirpophaga incertulas (LEPIDOPTERA: CRAMBIDAE) FROM WEST JAVA
}

\author{
RIKA RAFFIUDIN ${ }^{1 *}$, RUTH MARTHA WINNIE ${ }^{1}$ I MADE SAMUDRA ${ }^{2}$ \\ ${ }^{1}$ Department of Biology, Bogor Agricultural University (IPB), Darmaga, \\ Bogor 16680, INDONESLA \\ ${ }^{2}$ Indonesian Centre for Agricultural Biotechnology and Genetic Resources \\ Research and Development (ICABGRD)
}

\begin{abstract}
Yellow rice stem borer (Scirpophaga incertulas) is one of the most important rice pest insects in Asia, including Indonesia. However, there is a lack of genetic data for this important agricultural insect. Therefore, this study was conducted to explore intraspecific differentiation of $S$. incertulas partial 16S mitochondrial gene from Bogor, Karawang, Indramayu and Cirebon (West Java, Indonesia). Here, we reported a total of $325 \mathrm{bp}$ of $16 \mathrm{~S}$ mitochondrial gene of $S$. incertulas from the obtained samples. Among all DNA sequences, three haplotypes of $16 \mathrm{~S}$ mitochondrial gene were observed and submitted to GenBank under Accession Number of GU191881, GU191882, GU191883, respectively for haplotype 1, 2, and 3. The haplotype 1 was found in all S. incertulas surveyed locations, except Bogor. Haplotype 2 and 3 were found only in from Cirebon and Bogor samples. These haplotype variations can be applied as DNA markers for $S$. incertulas early larva detection method among other rice stem borers. Hence, further explorations of the mitochondrial variations of $S$. incertulas in Java and other parts of Indonesia are needed.
\end{abstract}

Key words: moth, haplotypes, genetic differentiations, molecular identification

\section{INTRODUCTION}

Yellow rice stem borer (Scirpophaga incertulas) is one of the most important rice pest insects in Asia, including Indonesia, that highly reduces rice yield. They are dominantly spread in the north coast of Java (or Pantura region, known as rice production regions), i.e. Karawang, Subang, Indramayu and Cirebon (Hattori \& Siwi 1986). Larvae of yellow rice stem borer damage the rice stem, hence disturb nutrient translocation from

$\overline{\text { * Corresponding author : rika_r@cbn.net.id }}$ 
root to leaf (Pathak 1975). As a result, tillers at vegetative stage die, called dead hearth. Larvae of $S$. incertulas also infest the generative stage of rice; therefore producing empty panicles, called white head. Yield loss at the rice generative stage was $1-3 \%$ higher than that of vegetative stage.

Several methods were used to control the yellow rice stem borers such as by using pesticide, cleaning the infected area and controling their eggs. Almost 57 kinds of insecticides were prohibited to be applied for rice plant because of polluting the environment and decreasing natural enemies. White rice stem borer (S. innotata) was reported resistant to carbofuran insecticide (Soejitno et al. 1994).

Mitochondrial DNA is a suitable tool to examine inter- and intraspecies genetic differences due to higher evolution rate of genes compared to those in nuclear DNA (Li 1997). Moreover, the abundance of mitochondria in the cell provides sufficient materials for the analysis (Crozier 1977). Current study explores 16S mitochondrial gene of S. incertulas from Pantura regions. However, partial gene of $16 \mathrm{~S}$ available in GenBank are only from $S$. excerptalis, the sugarcane stem borer from Papua New Guinea (GenBank Acc Num AY32046) and from India Acc Num AY320460). Those two records were published by Lange et al. (2004) to clarify the phylogenetic relationship of moth members from Pyralidae and Crambidae in sugarcane stem borers based on $16 \mathrm{~S}$ and cytochrome oxidase II (COII) mitochondrial genes (Lange et al. 2004). They also suggested that many taxonomy data based on morphology need to be re-organized. Yellow rice stem borer was previously classified in the Family Pyralidae (Pathak 1975). Currently, Scirpophaga is classified in the Suborder Pyraloidea; Family Crambidae; Subfamily Schoenobiinae (Lange et al. 2004). Four species of rice stem borers commonly found in Java are yellow rice stem borer (S. incertulas), white rice stem borer (S. innotata), stripe rice stem borer (Chilo suppressalis), and pink rice stem borer (Sesamia inferens). Alteration of species domination was detected in a certain period, i.e. before 1995, in Subang, West Java, the dominant species was white stem borer; but later, yellow stem borer dominates the population (Suharto \& Usyati 2005).

In an attempt to build database of mitochondrial DNA of yellow rice stem borers in Indonesia, here we commenced the exploration of intraspecific differences of $S$. incertulas based on 16S mitochondrial gene in West Java (Bogor, Karawang, Indramayu and Cirebon). The results of $16 \mathrm{~S}$ variations of $S$. incertulas can be applied as DNA markers for early larva detection method among other rice stem borer.

\section{MATERIALS AND METHOD}

\section{S. incertulas Collection}

Yellow rice stem borer were collected from four localities in West Java, Indonesia. Those were from several subdistricts in Bogor, Karawang, Indramayu and Cirebon (Table 1). 
BIOTROPIA Vol. 18 No. 1, 2011

Table 1. Sample locations of moth S. incertulas in West Java, Indonesia.

\begin{tabular}{lll}
\hline Locations (Subdistrict, District) & Latitude & Longitude \\
\hline Sindang Barang, Bogor & $6^{\circ} 34$ '24.61” & $106^{\circ} 45^{\prime} 50.9^{\prime \prime}$ \\
Pedes, Karawang & $6^{\circ} 04$ '13.26” & $107^{\circ} 22^{\prime} 32.61^{\prime \prime}$ \\
Arjawinangun, Cirebon & $6^{\circ} 39^{\prime} 08.63^{\prime \prime}$ & $108^{\circ} 24^{\prime} 40.47^{\prime \prime}$ \\
Lelea, Indramayu & $6^{\circ} 24^{\prime} 14.75^{\prime \prime}$ & $108^{\circ} 11^{\prime} 12.59^{\prime \prime}$ \\
\hline
\end{tabular}

\section{DNA extraction and 16S Mitochondrial DNA amplification}

Yellow rice stem borer DNA was extracted by using CTAB extraction and ethanol precipitation, using thoraces as tissue source (Raffiudin \& Crozier 2007). The $16 \mathrm{~S}$ of mitochondrial gene of yellow rice stem borers were amplified by using forward primer 16ScbF: 5'-AAGAT'TT'TAATGATCGAACAG-3' and reverse primer 16ScbR 5'TGACTGTACAAAGGTAGCATA-3' (Simon et al. 1994). Amplifications were carried out in conditions of: initial denaturation at $94^{\circ} \mathrm{C}$ for $2 \mathrm{~min}$. then 40 cycles at: 92 ${ }^{\circ} \mathrm{C}$ for $45 \mathrm{~s} ; 50^{\circ} \mathrm{C}$ for $60 \mathrm{~s}, 72^{\circ} \mathrm{C}$ for $90 \mathrm{~s}$, and final extension at $72^{\circ} \mathrm{C}$ for 2 min (Lange et al. 2004).

\section{DNA sequencing and analysis}

Amplicon of $S$. incertulas $16 \mathrm{~S}$ gene was sequenced by using the same primer as in the amplifications. Homology of the DNA sequences was analysed by using BLAST (http:/blast.ncbi.nlm.nih.gov/Blast.cgi). DNA alignments were carried out by using Clustal X (Thompson et al. 1997) and sugar stem borer 16S gene S. excerptalis Gen Bank Acc. Num AY320460 from India and S. excerptalis AY320461 from Papua Nugini (PNG) were used as the outgroups. All haplotypes obtained from this research were submitted to GenBank. Tamura-Nei distance parameter implemented in MEGA 5.05 (Tamura et al. 2011) was used to reveal inter- and intraspecific genetic distance among S. incertulas and S. excerptalis $16 \mathrm{~S}$ mitochondrial gene.

\section{RESULTS AND DISCUSSION}

This study revealed the first mitochondrial data of yellow rice stem borer $16 \mathrm{~S}$ mitochondrial gene from West Java, which was approximately $325 \mathrm{bp}$. The moth $S$. incertulas 16S RNA gene sequences were AT rich with 65\% AT. However, the value was lower than that of sugarcane stem borer $S$. excerptalis $16 \mathrm{~S}$ gene $(79.01 \%$ AT) (Lange et al. 2004). BLAST analysis of S. incertulas $16 \mathrm{~S}$ gene showed $89 \%$ homology with sugarcane stem borer of $S$. excerptalis $16 \mathrm{~S}$ mitochondrial gene (e-value: $9 \mathrm{e}^{-104}$ ).

Among all $S$. incertulas $16 \mathrm{~S}$ mitochondrial gene sequences, we observed three haplotypes from Bogor, Karawang, Cirebon and Indramayu samples (Table 2, Fig. 1). The first 16S mitochondrial gene haplotype was the common haplotypes found from $S$. incertulas in three locations (Karawang, Indramayu and Cirebon), i.e samples number Sc14KR, Sc3ID, Sc2CB, respectively (Table 2). The second $16 \mathrm{~S}$ mitochondrial 
Intraspecific Variations of 16S Mitochondrial Gene Sequences of S. incertulas - Rika Raffiudin et al.

Table 2. Haplotype variations of $16 \mathrm{~S}$ mitochondrial gene of S. incertulas from Bogor, Karawang, Indramayu, and Cirebon (West Java)

\begin{tabular}{|c|c|c|c|c|c|}
\hline Haplotypes & Locations & $\begin{array}{l}\text { S. incer - tulas } \\
\text { sample code }\end{array}$ & $\begin{array}{l}\text { Nucleotide position } \\
\text { (see Figure } 1 \text { ) }\end{array}$ & $\begin{array}{l}\text { Nucleotide } \\
\text { variations }\end{array}$ & $\begin{array}{l}\text { GenBank } \\
\text { Acc Num }\end{array}$ \\
\hline \multirow{3}{*}{1} & Karawang & Sc14KR & & & \multirow{3}{*}{ GU191881 } \\
\hline & Indramayu & Sc3ID & & & \\
\hline & Cirebon & $\mathrm{Sc} 2 \mathrm{CB}$ & & & \\
\hline \multirow[b]{2}{*}{2} & Cirebon & Sc15CB & \multirow[b]{2}{*}{154} & \multirow[b]{2}{*}{$A \rightarrow G$} & \multirow[b]{2}{*}{ GU191882 } \\
\hline & Cirebon & Sc17CB & & & \\
\hline 3 & Bogor & Sc20BG & 129 & $\begin{array}{l}\text { T } \rightarrow \text { " -“" } \\
\text { (deletion) }\end{array}$ & GU191883 \\
\hline
\end{tabular}

Sc: S. incertulas; notation followed "Sc" = sample number and sample location, BG = Bogor, KR = Karawang, ID = Indramayu, $\mathrm{CB}=$ Cirebon

Table 3. Genetic distance based on $16 \mathrm{~S}$ mitochondrial gene among $S$. incertulas and $S$. excerptalis corrected with Tamura-Nei distance

\begin{tabular}{|c|c|c|c|c|c|c|c|c|}
\hline & 1 & 2 & 3 & 4 & 5 & 6 & 7 & 81 \\
\hline \multicolumn{9}{|l|}{ [1] } \\
\hline [2] & 0.000 & & & & & & & \\
\hline [3] & 0.003 & 0.003 & & & & & & \\
\hline [4] & 0.003 & 0.003 & 0.000 & & & & & \\
\hline [5] & 0.003 & 0.003 & 0.000 & 0.000 & & & & \\
\hline [6] & 0.003 & 0.003 & 0.000 & 0.000 & 0.000 & & & \\
\hline [7] & 0.145 & 0.145 & 0.142 & 0.142 & 0.142 & 0.142 & & \\
\hline [8] & 0.133 & 0.133 & 0.130 & 0.130 & 0.130 & 0.130 & 0.021 & \\
\hline
\end{tabular}

Abbreviations in Table 3 refer to Figure 1.

[1] Sc15CB.H2 [5] Sc3ID.H1

[2] Sc17CB.H2 [6] Sc14KR.H1

[3] Sc20BG.H3 [7] Se.India.AY320460

[4] Sc2CB.H1 [8] Se.PNG.AY320461

gene haplotype was found in both samples from Cirebon, having transition substitution at the nucleotide number 154 (Fig. 1, Table 2). Compared to 16S mitochondrial gene haplotype 1 and 2, haplotype 3 in S. incertulas Sc20Bg sample showed deletion of one nucleotide (number 129) (Fig.1). These three haplotypes were submitted to GenBank under Accesion Number GU191881, GU191882, GU191883.

Intraspecific genetic distance among $S$. incertulas in West Java based on $16 \mathrm{~S}$ mitochondrial gene revealed 0.003 . Further analysis of intraspecific genetic distance of $16 \mathrm{~S}$ gene between $S$. incertulas and $S$. excerptalis from India and PNG showed 0.145 and 0.133 , respectively (Table 3 ). These values were higher than genetic distance between $S$. incertulas and $S$. innotata, i.e. 0.063 (unpublished data).

Result of this study can be used for identification of yellow rice stem borer in the early instar larvae. This is due to the morphology of rice stem borers larvae which show slightly differences between yellow and white rice stem borers, hence careful examination is needed (Amir et al. 2004). Phylogenetic analysis frequently establishing inter- and intra specific relationship between taxa and within populations as well. This was shown in several mitochondrial genes i.e. COI, ND1, and 16 S that were used 
BIOTROPIA Vol. 18 No. 1, 2011

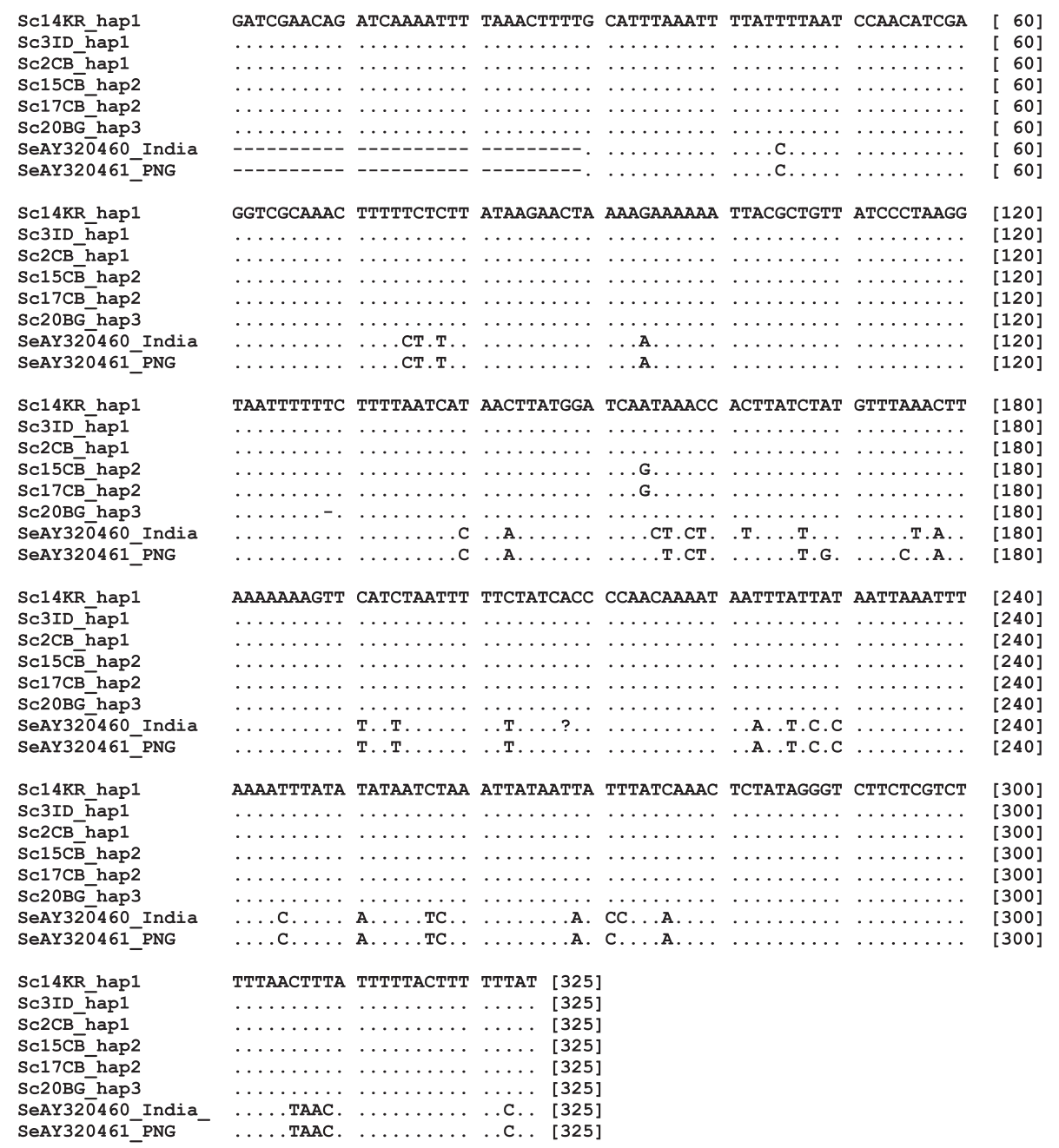

Figure 1. DNA alignments of $16 \mathrm{~S}$ mitochondrial gene of S. incertulas from Bogor (BG), Karawang (KR), Indramayu (ID), Cirebon (CB), and S. excerptalis from India and PNG; " "” = homology of nucleotides in the same column. Sc: Scirpophaga incertulas (yellow rice stem borer), Se: Scirpophaga excerptalis (sugar cane stem borer). Notation followed "Sc" = sample number, sample location and haplotype number; AY320460 and AY320461 mentioned after "Se" = GenBank (www.ncbi.nlm.nih.gov) Acc. Num. for S. excerptalis from India and PNG

to construct a molecular phylogeny of butterflies belonging to the genus Euphydryas s.l.. Euphydryas s.l. has been divided into four genera in an earlier revision. The current results showed three well-supported groups within the genus, corresponding to three of the four proposed genera (Zimmermann et al. 2000). Another example was on the basis of $16 \mathrm{~S}$ ribosomal DNA and COI-COII regions that revealed restriction-site variations in geographically divergent collections of tobacco budworm, Heliothis virescens (F.) Tennesse, Mississippi, Oklahoma, and Texas (Roehrdanz et al. 1994). 
This study explored three haplotypes of $S$. incertulas in several regions in West Java, however, a further exploration is needed to reveal the complete genetic intraspecific variations of this agricultural importance insect. Database of mitochondrial variations from rice stem borer can be applied for further monitoring strategy to examine the dynamic population of the stem borer, to seek both the origin of this pest and the relationships among other species of rice stem borer. Moreover, this result can be used as a basic data to establish enviromental safely control method such as by disrupting the mating time of the stem borer (Samudra et al. 2002) and characterise the sex pheromone of S. incertulas to disrupt the mating behaviour (Tatsuki et al. 1985).

\section{CONCLUSIONS}

This study was the first report for intraspecific differentiation of S. incertulas basedon $16 \mathrm{~S}$ mitochondrial gene obtained from Bogor, Karawang, Indramayu and Cirebon (West Java, Indonesia) samples. Three haplotypes of $16 \mathrm{~S}$ mitochondrial gene were observed and submitted to GenBank under Accession Number: GU191881, GU191882, GU191883, respectively for S. incertulas 16 S mitochondrial gene haplotype 1,2 , and 3. Haplotype 1 of $16 \mathrm{~S}$ mitochondrial gene was found in almost all locations, except Bogor. Haplotype 2 and 3 were found only in S. incertulas from Cirebon and Bogor samples. Further explorations of $S$. incertulas $16 \mathrm{~S}$ mitochondrial gene in Java and other parts of Indonesia are needed to reveal complete 16S gene intraspecific differentiations of this agricultural importance insect.

\section{ACKNOWLEDGEMENTS}

Funding for this research was provided by SEAMEO-BIOTROP and is gratefully acknowledged.

\section{REFERENCES}

Amir M, Kartohardjono A, Siwi S, Ubaidillah R. 2004. Morphological species variability in the stemborer genus Scirphopaga (Lepidoptera:Pyralidae) on graminous crops. Treubia 33:147-163

Crozier RH. 1977. Evolutionary genetics of the Hymenoptera. Annual Review of Entomology 22:263-288

Hattori I, Siwi S. 1986 Rice stemborers in Indonesia. JARQ 20:25-30

Lange CL, Scott KD, Graham GC, Sallam MN, Allsopp PG. 2004. Sugarcane moth borers (Lepidoptera: Noctuidae and Pyraloidea): phylogenetics constructed using COII and 16S mitochondrial partial gene sequences. Bulletin of Entomological Research 94:457-464

Li WH. 1997. Molecular Evolution. Sinauer Associates, Inc. Publishers, Massachusetts

Pathak MB. 1975. Insects Pest of Rice. International Rice Research Institute, Los Banos

Raffiudin R, Crozier RH. 2007. Phylogenetic Analysis of Honeybee behavioural evolution. Molecular Phylogenetics and Evolution 43:543-552 
BIOTROPIA Vol. 18 No. 1, 2011

Roehrdanz RL, Lopez JD, Loera J, Hendricks DE. 1994. Limited mitochondrial DNA polymorphism in North American populations of Heliothis virescens (Lepidoptera: Noctuidae). Annals of the Entomological Society of America 87:856-864

Samudra I, Emura K, Hoshizaki S, Ishikawa Y, Tatsuki S. 2002. Temporal differences in mating behavior between rice- and water-oats-populations of the striped stem borer, Chilo suppressalis (Walker) (Lepidoptera: Crambidae). Applied Entomology and Zoology 37:257-262

Simon C, Frati F, Beckenbach A, Crespi B, Liu H, Flook P. 1994. Evolution, weighting, and phylogenetic utility of mitochondrial gene sequences and a compilation of conserved polymerase chain reaction primers [Review]. Annals of the Entomological Society of America 87:651-701

Soejitno J, Samudra IM, Kilin D. 1994. Kajian ketahanan penggerek padi putih, Scirpophaga innotata Walker terhadap insektisida karbofuran. Penelitian Pertanian 14:78-83

Suharto H, Usyati N. 2005. The stem borer infestation on rice cultivars at three planting times. Indonesian Journal of Agricultural Science 6:39-45

Tamura K, Peterson D, Peterson N, Stecher G, Nei M, Kumar S. 2011. MEGA5: Molecular Evolutionary Genetics Analysis using Maximum Likelihood, Evolutionary Distance, and Maximum Parsimony Methods. Molecular Biology and Evolution 28:2731-2739

Tatsuki S, Sugie H, Usui K, Fukami J, Sumartapura MH, Kuswadi AN. 1985. Identification of possible sex pheromone of the yellow stem borer moth, Scirpophaga incertulas (Walker) (Lepidoptera: Pyralidae). . Applied Entomology and Zoology 20:357-359

Thompson JD, Gibson TJ, Plewniak F, Jeanmougin F, Higgins DG. 1997. The Clustal-X windows interface: flexible strategies for multiple sequence alignment aided by quality analysis tools. Nucleic Acid Research 25:4876-4882

Zimmermann M, Wahlberg N, Descimon H. 2000. Phylogeny of Euphydryas Checkerspot Butterflies (Lepidoptera: Nymphalidae) Based on Mitochondrial DNA Sequence Data. Annals of the Entomological Society of America 93:347-355. 